\title{
Ovary Structure in the Costaceae (Zingiberales)
}

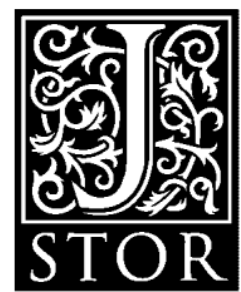

\author{
S. Winnell H. Newman, Bruce K. Kirchoff \\ International Journal of Plant Sciences, Volume 153, Issue 3, Part 1 (Sep., 1992), \\ 471-487.
}

Newman, S. W. and B. K. Kirchoff. 1992. Ovary structure in the Costaceae

(Zingiberales). International Journal of the Plant Sciences 153: 471-487.

Made available courtesy of University of Chicago Press:

http://www.journals.uchicago.edu/doi/abs/10.1086/297054

Your use of the JSTOR archive indicates your acceptance of JSTOR' s Terms and Conditions of Use, available at http://www.jstor.org/about/terms.html. JSTOR' s Terms and Conditions of Use provides, in part, that unless you have obtained prior permission, you may not download an entire issue of a journal or multiple copies of articles, and you may use content in the JSTOR archive only for your personal, non-commercial use.

Each copy of any part of a JSTOR transmission must contain the same copyright notice that appears on the screen or printed page of such transmission.

International Journal of Plant Sciences is published by University of Chicago Press. Please contact the publisher for further permissions regarding the use of this work. Publisher contact information may be obtained at http://www.jstor.org/journals/ucpress.html.

International Journal of Plant Sciences

(C) 1992 University of Chicago Press

JSTOR and the JSTOR logo are trademarks of JSTOR, and are Registered in the U.S. Patent and Trademark Office. For more information on JSTOR contact jstor-info@ @mich.edu.

C2001 JSTOR

http://www.jstor.org/ 


\title{
OVARYSTRUCTUREINTHECOSTACEAE(ZINGIBERAIES)
}

\author{
S. WINNELL H. NEWMAN AND BRUCE K. KIRCHOFF' \\ Department of Biology, University of North Carolina, Greensboro, North Carolina 27412-5001
}

\begin{abstract}
The morphology and histology of the ovary is investigated in four species representing the four genera of the family Costaceae. Only one species of Costus has been investigated prior to this study. The present study identifies new characters and confirms or corrects those previously reported for all four genera. Aspects of ovary structure studied include the general topography and histology of the ovary, paths of the stylar canals, the prolongation of the ovary above the locules, the presence of a vascular plexus at the top of the ovary, and the position and structure of the floral nectary. These characters contribute to a broader data base for phylogenetic analysis of the Zingiberales.
\end{abstract}

\section{Introduction}

The Costaceae are monocotyledons belonging to the order Zingiberales. The Zingiberales are a natural order consisting of the eight families Zingiberaceae, Costaceae, Marantaceae, Cannaceae, Lowiaceae, Musaceae, Heliconiaceae, and Strelitziaceae (Nakai 1941; Tomlinson 1962; Takhtajan 1969, 1980). Within this group, the Costaceae and Zingiberaceae are sister taxa (Dahlgren and Rasmussen 1983; Kress 1990). The Costaceae are characterized by spiral monostichous phyllotaxy, closed leaf sheaths, a nectary gland in the top of the ovary, and the lack of aromatic compounds. The Zingiberaceae are characterized by distichous phyllotaxy, open leaf sheaths, epigynous glands in the flower, and the possession of aromatic compounds.

The four genera of the Costaceae (Costus, Monocostus, Dimerocostus, and Tapeinocheilas) are found in tropical and subtropical areas throughout the Old and New World-in rain forests and other moist, shady sites. The 20 species of Tapeinocheilas occur mostly in Indonesia, New Guinea, and Australia (Queensland) (Maas 1972, 1977). The monotypic genus Monocostus is restricted to the Huallaga River region in central Peru (Maas 1972, 1977). Dimerocostus has two species and occurs from Central America to central Bolivia (Maas 1972, 1977). Costus, the largest genus, with 125-175 species, has a pantropical distribution. Maas (1972, 1977) separates Costus into the subgenera Costus and Cadalvena.

Schumann (1904) was the first to recognize the four genera Costus, Monocostus, Dimerocostus, and Tapeinocheilas as the subfamily Costoideae of the Zingiberaceae. This treatment held until Nakai (1941) separated the Costoideae from the remainder of the Zingiberaceae as the family Costaceae. Tomlinson's $(1956,1962)$ studies of the morphology and anatomy of the Zingiberaceae (sensu lato) support this separation.

\footnotetext{
' Author for correspondence and reprints.
}

Manuscript received October 1991; revised manuscript received March 1992.
Aside from work on the single species Costus speciosus (Brown 1938; Rao et al. 1954; Pai 1966; Van Heel 1988), the majority of information on ovary structure in the Costaceae comes from taxonomic work on this family (Maas 1972, 1976, 1977, 1979, 1985). The data on internal and external ovary structure that can be extracted from Maas's work are sparse, as befits taxonomic treatments. Nevertheless, these articles serve as a source of basic ovary characters such as the number of locules and the presence of septal nectaries.

The purpose of the present study is to investigate ovary structure to identify new structural characters that can be used in phylogenetic analyses. We have also attempted to confirm the literature data on the structure of the ovary in the Costaceae. Increased knowledge of ovary structure in the Costaceae will broaden the data base used in analysis of evolutionary relationships in this family. In his taxonomic review of the Zingiberaceae (sensu lato), Panchaksharappa (1962) pointed out the necessity for examining the remaining three genera of the Costoideae for possession of the same features as Costus and stated that such results would go a long way in the taxonomic evaluation of the family.

\section{Materialandmethods}

Mature flowers of the Costaceae were collected from Lyon and Waimea Arboreta, Oahu, Hawaii: Costus dubius (Afz.) K. Schuman (Waimea accession no. 82P837), Tapeinocheilas ananassae K. Schuman (Waimea accession no. 74P753, voucher: Kirchoff 88-140 at BISH), Dimerocostus strobilaceus 0. Kuntze ssp. strobilaceus (Lyon accession no. 78.1074, voucher: Kirchoff 88-148 at BISH), Monocostus uniflorus (Poegg. ex O.G. Petersen) Maas (Waimea accession no. 76P641, voucher: Kirchoff 87-110 at BISH). Anatomical data were collected from five to seven ovaries of each species.

Specimens were fixed and stored in FAA (Berlyn and Miksche 1976). Sections were prepared using standard paraffin techniques (Berlyn and Miksche 1976) with the following additions. To remove tannins, the ovaries were soaked in 
Stockwell's bleach (Johansen 1940) for 5-15 d and rinsed in Sorensen's phosphate buffer, $\mathrm{pH}$ 7.2, prior to dehydration. Dehydration was either with a t-butyl alcohol series (Berlyn and Miksche 1976) or with 2,2-dimethoxypropane (Postek and Tucker 1976). There was no noticeable difference in the specimen using either method of dehydration. The specimens were then transferred to $100 \%$ t-butyl alcohol and embedded in paraffin. Sections were cut on an American Optical rotary microtome or a Reichert 2040 Autocut microtome at 10-20 Am and mounted on slides using Bissing's modified Haupt's adhesive (Bissing 1974). The sections were stained with safraninfast green (Berlyn and Miksche 1976), dewaxed using ClearRite III in place of xylene, and mounted with Permount. Photomicrographs were taken with Leitz Ortholux II and Wild M5A photomicroscopes.

Longitudinal measurements of the following portions of the ovary were made: the distance from pedicel to perianth attachment, the length of the locules, the length of the prolongation above the locules, and the length of the secretory tissue of the nectary (table 1). These measurements were made using one of three procedures. (1) Sagittal sections of whole ovaries were measured using calipers. (2) Longitudinal sections mounted on slides were measured using an ocular micrometer on an Olympus SZH stereomicroscope. (3) Longitudinal distances were calculated from serial cross sections counting the number of serial sections on slides and multiplying by the section thickness. Means and standard deviations were calculated.

The median plane of the flower bisects the inflorescence axis, the flower pedicel, and the main axis of the flower. We refer to the side of the ovary away from the inflorescence axis as abaxial (or anterior) and the side adjacent to the inflorescence axis as adaxial (or posterior). Anterolateral and posterolateral refer to the lateral regions of the flower, just off the median plane, on the anterior and posterior sides of the flower, respectively. We use the term "carpel" only in a descriptive sense.

\section{Results}

HABIT AND MORPHOLOGY OF COSTACEAE (FIGS. 1, 2)

The Costaceae are herbaceous monocotyledons with sympodial rhizomes, well-developed aerial shoots, terete stems that are often helically twisted, and usually unbranched aerial shoots; Tapeinocheilas and some Costus spp. have branched shoots. The leaves are arranged in spiral monostichous phyllotaxy. Each leaf consists of a closed tubular sheath and an entire, lanceolate, or oblanceolate to linear lamina with an acumi nate apex. A ligule is present at the junction of the sheath and blade.

The inflorescence is an ovoid to cylindrical spike or thyrse with bracts and flowers arranged in a spiral monostichous or fibonacci helix. The inflorescence is terminal on the end of a leafy ( $D i$ merocostus, some Costus spp.) or separate leafless shoot (Tapeinocheilas, some Costus spp.), or the flowers are borne in the axils of foliage leaves (Monocostus). In Dimerocostus the shoot/inflorescence apex continues to grow past the inflorescence, frequently producing a second inflorescence on the same shoot (fig. 1).

The flowers of the Costaceae are bisexual and zygomorphic (figs. 1,2). The sepals are greenish and fused into a synsepalous, trilobate calyx. The lobes are generally triangular to deltoid, and acuminate. In Tapeinocheilas the calyx is coriaceous; in the other three genera it is herbaceous. In all of the genera, the petals are longer than the sepals and fused basally but become free where exerted above the calyx. The medial member of the corolla is often longer than the laterals. All members of the androecial whorls but one, the medial member of the inner whorl, are represented by petaloid staminodes and are fused to form a conspicuous, often three-lobed, labellum. The labellum is white or conspicuously colored. The size and texture of the labellum varies across the family from relatively small and callose to large and delicate (fig. 1). The single polleniferous stamen is the median member of the inner whorl and is inserted opposite the labellum. The filament is petaloid and fleshy with the anther attached on the adaxial surface, near the apex. The ovary is inferior with numerous ovules on axile placentas. The ovules are anatropous and crassinucellate. The long, slender style is clasped between the thecae of the anther.

\section{STRUCTURE OFTHE OVARY (FIGS. 3-13)}

The ovary may be divided into three relatively distinct regions based on the longitudinal position of the locules (figs. 3a, 4a, 5a, 6a). The central and most prominent region contains the locules and is referred to as the locular region. Below this is the sublocular region, which is short and closes the locules from below. The third region, the area above the locules, is termed the prolongation. Normally an inferior ovary is closed above the locules with a small cap of tissue. In some genera of Costaceae, this cap is extended into a prolonged closure. A main distinction between the locular and prolongation regions is the lack of locules in the latter. There may or may not be an external indication of the presence of the prolongation. A vascular plexus occurs in the vascular zone of the prolongation, and a floral nectary is present near the top of the ovary in the central axis of the flower. 
Table

OVARY STRUCTURE AND HISTOLOGY IN INDIVIDUAL SPECIES

\begin{tabular}{|c|c|c|c|c|}
\hline & Monocostus uniflorus & Tapeinocheilas ananassae & Dimerocostus strobilaceus & Costus dubius \\
\hline $\mathrm{N}$ & 6 & 7 & 5 & 7 \\
\hline $\begin{array}{l}\text { Organography: } \\
\text { Length of }(\mathrm{mm} \pm \mathrm{SD}) \text { : }\end{array}$ & & & & \\
\hline \multicolumn{3}{|l|}{ Length of $(\mathrm{mm} \pm \mathrm{SD})$ : } & $21.3 \pm 1.65$ & \\
\hline $\begin{array}{l}\text { Ovary } \ldots \ldots \ldots \ldots \ldots \ldots \ldots \ldots \ldots \\
\text { Locular region } \ldots \ldots \ldots \ldots \ldots \ldots \ldots\end{array}$ & $\begin{aligned} 14.2 & \pm .92 \\
9.7 & \pm .82\end{aligned}$ & $\begin{aligned} & 11.9 \pm 1.11 \\
& 8.8 \pm 1.14\end{aligned}$ & $\begin{array}{l}21.3 \pm 1.65 \\
1.17 \pm 1.41\end{array}$ & $\begin{array}{l}8.9 \pm 1.17 \\
7.0 \pm .92\end{array}$ \\
\hline $\begin{array}{l}\text { Locular region } \ldots \ldots \ldots \ldots \ldots \ldots \ldots, \\
\text { Prolongation } \ldots \ldots \ldots \ldots \ldots \ldots \ldots\end{array}$ & $\begin{array}{l}9.7 \pm .82 \\
2.2 \pm .27\end{array}$ & $2.1 \pm .31$ & $7.5 \pm .77$ & $\begin{array}{l}1.0 \pm .92 \\
1.4 \pm .47\end{array}$ \\
\hline & $\begin{array}{l}2.2 \pm .27 \\
2.7 \pm .15\end{array}$ & $3.5 \pm .47$ & $5.9 \pm 1.42$ & $2.7 \pm .74$ \\
\hline \multicolumn{5}{|l|}{ Cross-sectional shape of: } \\
\hline Sublocular region ...... & Round to oval & Oval and slightly biwinged & Circular & Oval \\
\hline Locular region & $\begin{array}{l}\text { Proximally, oval; distally, round- } \\
\text { ed triangular }\end{array}$ & $\begin{array}{l}\text { Rounded triangular with pro- } \\
\text { nounced wings }\end{array}$ & $\begin{array}{l}\text { Rounded triangular and slightly } \\
\text { biwinged }\end{array}$ & Rounded rectangular \\
\hline Prolongation . & Rounded triangular & $\begin{array}{l}\text { Rounded triangular, wings less } \\
\text { pronounced }\end{array}$ & $\begin{array}{l}\text { Rounded triangular to oval and } \\
\text { slightly biwinged }\end{array}$ & Oval to round \\
\hline Ovary symmetry. & Bilateral & Bilateral & Bilateral & Radial \\
\hline \multicolumn{5}{|c|}{ Aerenchyma abaxial to central axis in } \\
\hline No. of locules ................... & & & & 3 \\
\hline Longitudinal extent of ovules.. & Below insertion of stylar canal & Below insertion of stylar canal & Below insertion of stylar canal & $\begin{array}{l}\text { Above and below insertion of sty- } \\
\text { lar canal }\end{array}$ \\
\hline No. of rows of ovules/locule. . & 2 & 2 & 4 & 4 \\
\hline Stylar canal insertion $\ldots \ldots \ldots \ldots$ & Lateral & Lateral & Apical & Lateral \\
\hline $\begin{array}{l}\text { No. of stylar canals in proximal } \\
\text { prolongation } \ldots \ldots \ldots \ldots \ldots \ldots\end{array}$ & 2 & 2 & 2 & 3 \\
\hline \multicolumn{5}{|l|}{$\begin{array}{l}\text { prolongation................... } \\
\text { No. of stylar canals in distal }\end{array}$} \\
\hline Stylar canals fuse . . . . . . . . & Below perianth & In style & Below perianth & $\begin{array}{l}3 \\
\text { Below perianth }\end{array}$ \\
\hline Nectary placement & $\begin{array}{l}\text { Between locules and in prolonga- } \\
\text { tion }\end{array}$ & $\begin{array}{l}\text { Between locules and in prolonga- } \\
\text { tion }\end{array}$ & In prolongation & $\begin{array}{l}\text { Between locules and in prolonga- } \\
\text { tion }\end{array}$ \\
\hline Secretory tissue & Smoothly rounded lobes & $\begin{array}{l}\text { Highly convoluted finger-like } \\
\text { projections }\end{array}$ & $\begin{array}{l}\text { Highly convoluted finger-like } \\
\text { projections }\end{array}$ & Smoothly rounded lobes \\
\hline No. of nectary ducts in prolongation ... & 1 & 2 & 1 & 2 \\
\hline \multicolumn{5}{|l|}{ Histology, sublocular region: } \\
\hline $\begin{array}{l}\text { Epidermis: } \\
\text { Cell shape }\end{array}$ & Cuboidal to rectangular & \multicolumn{3}{|c|}{ Epidermis: } \\
\hline Outer wall. & Thickened & Not thickened & Not thickened & $\begin{array}{l}\text { Rectangular to cubordal } \\
\text { Not thickened }\end{array}$ \\
\hline Trichomes. & Absent & Multicellular, uniseriate & Unicellular & Absent \\
\hline Hypodermis . & Present & Absent & Present & Present \\
\hline No. of cell layers $\ldots \ldots \ldots \ldots \ldots$ & 1 & NA & & 3 \\
\hline Cell shape $\ldots \ldots \ldots \ldots \ldots \ldots$ & Columnar & NA & Isodiametric & Columnar \\
\hline \multicolumn{5}{|c|}{ Vascular zone: } \\
\hline Ground tissue .... & Isodiametric parenchyma cells & Isodiametric parenchyma cells & Isodiametric parenchyma cells & Aerenchyma \\
\hline Bundles arranged. & $\begin{array}{l}\text { One ring with additional bundles } \\
\text { in center }\end{array}$ & Irregularly arranged & $\begin{array}{l}\text { One ring with additional bundles } \\
\text { in center }\end{array}$ & $\begin{array}{l}\text { One ring with additional bundles } \\
\text { in center }\end{array}$ \\
\hline
\end{tabular}


Table 1 (Continued)

\begin{tabular}{|c|c|c|c|c|}
\hline & Monocostus uniflorus & Tapeinocheilas ananassae & Dimerocostus strobilaceus & Costus dubius \\
\hline \multicolumn{5}{|l|}{ Histology, locular region: } \\
\hline \multicolumn{5}{|l|}{ Epidermis: } \\
\hline Cell shape & Cuboidal to rectangular & Cuboidal & Cuboidal & Rectangular to cuboidal \\
\hline Outer wall & Thickened & Not thickened & Not thickened & Not thickened \\
\hline Trichomes. & Absent & Multicellular, uniseriate & Unicellular & Absent \\
\hline Hypodermis . & Present & Present in upper half of region & Present & $\begin{array}{l}\text { Present, differs proximally and } \\
\text { distally }\end{array}$ \\
\hline No. of cell layers & 1 & $5-10$ & $2-4$ & Proximally, 2 ; distally, 4 \\
\hline Cell shape..... & $\begin{array}{l}\text { Proximally, columnar; distally, } \\
\text { very thin and long columnar }\end{array}$ & Isodiametric & $\begin{array}{l}\text { Proximally, isodiametric; distal- } \\
\text { ly, columnar }\end{array}$ & $\begin{array}{l}\text { Proximally, columnar; distally, } \\
\text { isodiametric }\end{array}$ \\
\hline \multicolumn{5}{|c|}{ का } \\
\hline Ground tissue & Isodiametric parenchyma cells & Isodiametric parenchyma cells & Isodiametric parenchyma cells & Aerenchyma \\
\hline Ground tissue cell layers & $8-16$ & $10-20$ adaxially; $15-20$ abaxially & $15-20$ & NA \\
\hline \multicolumn{5}{|c|}{ No. of isodiametric parenchyma cell } \\
\hline layers adjacent to locule epithelium & 1 & 2 & $2-3$ & $1-2$ \\
\hline Locule epithelium $\ldots \ldots \ldots \ldots \ldots \ldots$ & Cuboidal to rectangular & Cuboidal to squamous & Cuboidal & Rectangular to cuboidal \\
\hline Stylar canal epithelium $\ldots \ldots \ldots \ldots$ & Cuboidal to columnar & Cuboidal & Columnar & Cuboidal \\
\hline Nectary ............. & Present at this level & Present at this level & Absent at this level & Present at this level \\
\hline \multicolumn{4}{|c|}{ No. of layers of isodiametric paren- } & $2-8$ \\
\hline Duct epithelium ................ & Rectangular & Cuboidal & NA & Rectangular \\
\hline Duct walls facing lumen & Not thickened & Thickened & NA & Thickened \\
\hline Secretory epithelium ....... & Columnar & Cuboidal to columnar & NA & Columnar \\
\hline \multicolumn{5}{|l|}{ Central axis: } \\
\hline Proximally. & $\begin{array}{l}\text { Isodiametric parenchyma inter- } \\
\text { spersed with vasculature }\end{array}$ & $\begin{array}{l}\text { Isodiametric parenchyma inter- } \\
\text { spersed with vasculature }\end{array}$ & $\begin{array}{l}\text { Isodiametric parenchyma and } \\
\text { aerenchyma; vasculature ar- } \\
\text { ranged in band between loc- } \\
\text { ules }\end{array}$ & $\begin{array}{l}\text { Isodiametric parenchyma inter- } \\
\text { spersed with vasculature }\end{array}$ \\
\hline Distally & Nectary present & Nectary present & $\begin{array}{l}\text { Nectary absent; vasculature in } \\
\text { center of axis }\end{array}$ & Nectary present \\
\hline \multicolumn{5}{|l|}{ Prolongation: } \\
\hline \multicolumn{5}{|l|}{ Epidermis: } \\
\hline Cell shape & Cuboidal & Cuboidal & Cuboidal & Rectangular \\
\hline Outer wall & Thickened & Not thickened & Not thickened & Not thickened \\
\hline Trichomes. & Absent & Multicellular, uniseriate & Unicellular & Unicellular \\
\hline Hypodermis & Present & Present & Present & Present \\
\hline No. of cell layers & 1 & $5-10$ & $2-4$ & $2-4$ \\
\hline Cell shape $\ldots \ldots \ldots \ldots \ldots \ldots \ldots$ & Columnar & Isodiametric & Columnar & Isodiametric \\
\hline \multicolumn{5}{|l|}{ Vascular zone: } \\
\hline Differs proximally and distally & No & No & No & Yes \\
\hline Ground tissue layers ........... & $3-8$ & $10-20$ abaxially; $20-40$ adaxially & $40-50$ & $\begin{array}{l}\text { Proximally, } 30 \text {; distally, 6-10 in } \\
\quad c 1,20 \text { in } c 2^{\mathrm{a}}\end{array}$ \\
\hline
\end{tabular}




\begin{tabular}{|c|c|c|c|c|}
\hline & Monocostus uniflorus & Tapeinocheilas ananassae & Dimerocostus strobilaceus & Costus dubius \\
\hline \multicolumn{5}{|l|}{$\begin{array}{l}\text { No. of rings of vascular bundles in } \\
\text { addition to scattered bundles }\end{array}$} \\
\hline present .................... & 2 & 2 & 1 & $\begin{array}{l}\text { 3; location differs proximally and } \\
\text { distally }^{\mathrm{a}}\end{array}$ \\
\hline Stylar canal epithelium & Cuboidal & Cuboidal & Cuboidal to columnar & Cuboidal \\
\hline $\begin{array}{l}\text { Stylar canal surrounded by ........... } \\
\text { Nectary }\end{array}$ & Parenchyma & Sclerified cells & Sclerified cells & Parenchyma \\
\hline $\begin{array}{l}\text { No. of layers of isodiametric paren- } \\
\text { chyma cells surrounding nectary }\end{array}$ & $1-2$ & $2-5$ & $4-5$ & Absent \\
\hline $\begin{array}{l}\text { Acrenchyma external to } \\
\text { parenchyma....................... }\end{array}$ & Present & Present & Present & Absent \\
\hline Duct epithelium ........ & Cuboidal & Cuboidal to columnar & Cuboidal & $\begin{array}{l}\text { Proximally, cuboidal; distally, } \\
\text { rectangular }\end{array}$ \\
\hline Duct walls facing lumen. & Thickened & Not thickened & Not thickened & Thickened \\
\hline Secretory epithelium . & Columnar & Columnar & Cuboidal to mostly columnar & Columnar \\
\hline Outer wall of secretory epithelium.. & Not thickened & Thickened & Not thickened & Not thickened \\
\hline
\end{tabular}

Note. Order of characters is the same as in the General Description. Characters that are uniform across all four species are not included in the table. NA, not applicable.
See text for fuller explanation.
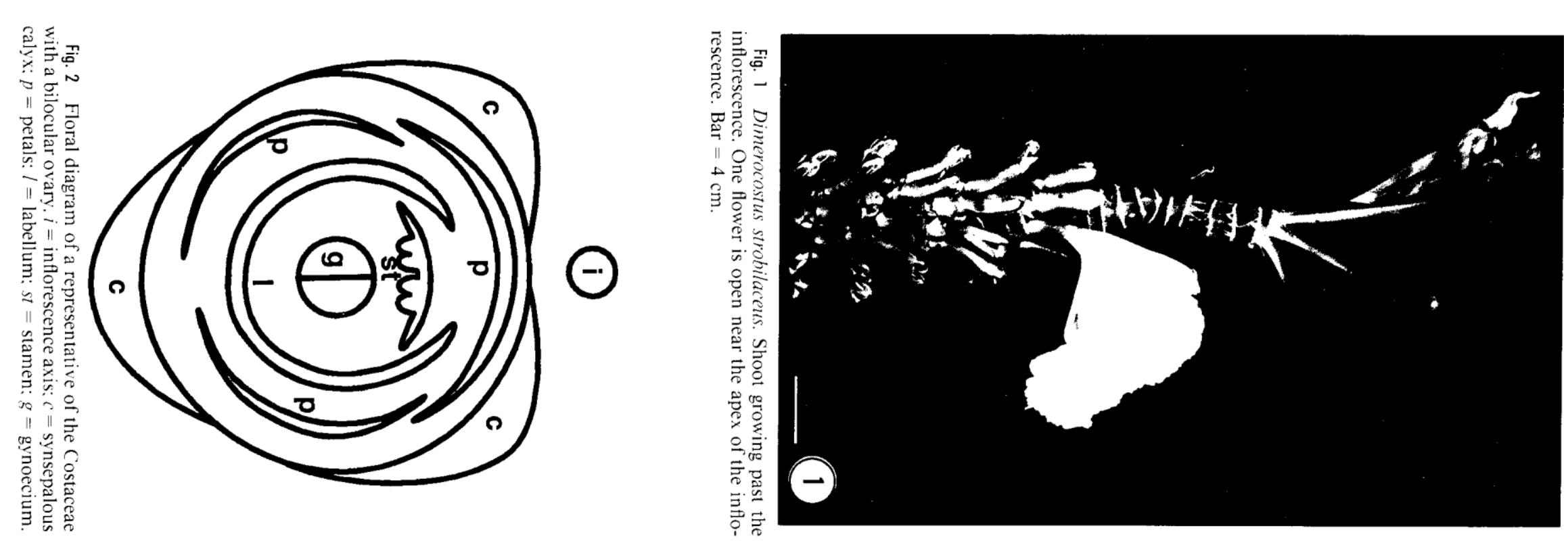


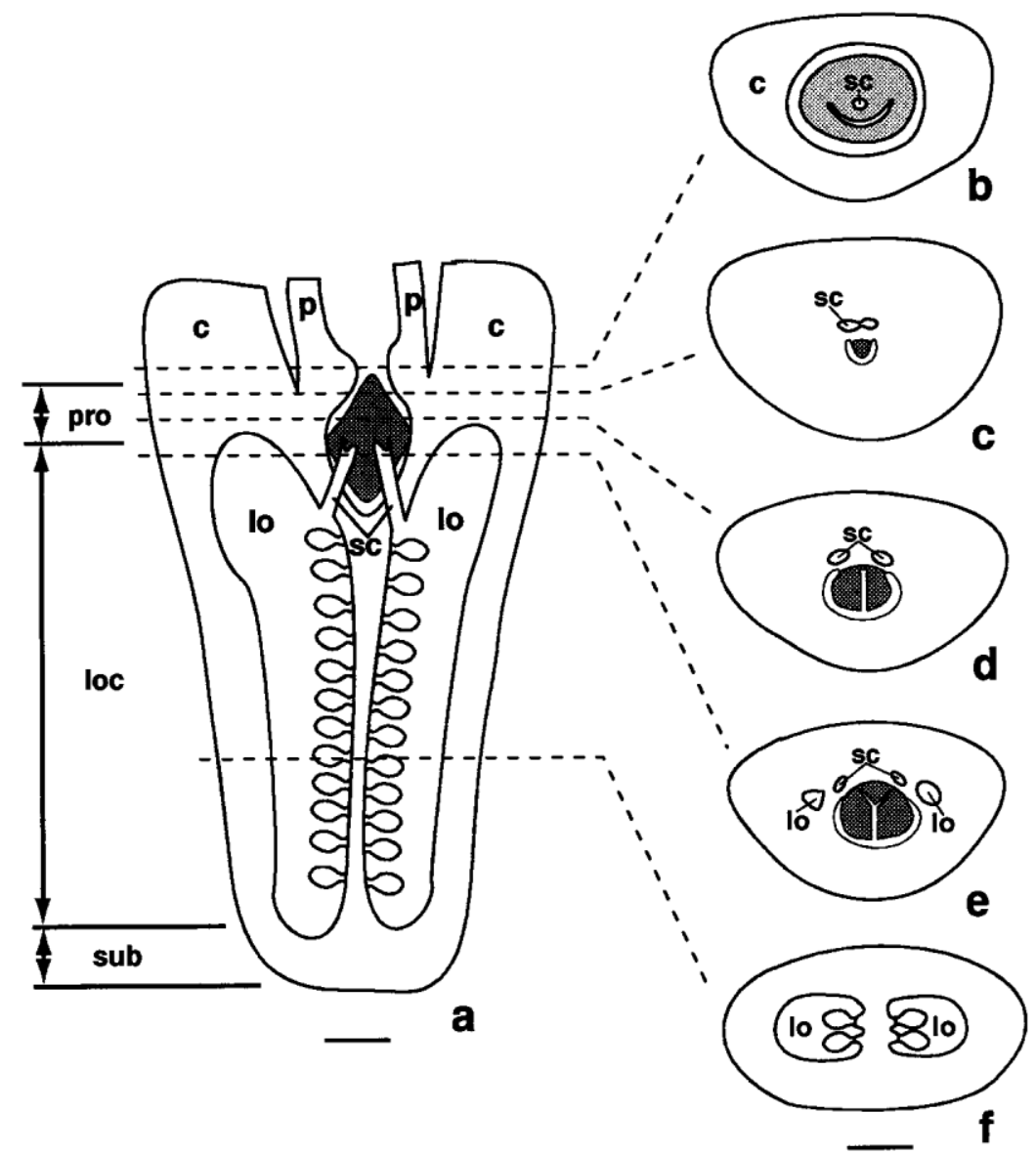

Fig. 3 Diagrams of mature ovary of Monocostus uniflorus. a, Longitudinal diagram of the ovary. The three regions of the ovary are the sublocular (sub), locular (loc), and prolongation (pro). The nectary (shaded) lies between the tops of the locules (lo) and in the prolongation. $c=$ synsepalous calyx; $p=$ petals; $s c=$ stylar canals (truncated; see $b-e$ for their course); bar $=$ $1.57 \mathrm{~mm} . b-f$. Cross sections of the ovary at the levels indicated in $a$. Bar $=1.1 \mathrm{~mm}$. $b$, Perianth attachment. $c=$ synsepalous calyx; lightly shaded area = corolla and style; $s c=$ stylar canal; curved slit = nectary pore at top of ovary. $c$, Distal portion of the prolongation. A bilobed stylar canal $(s c)$ is present in the central axis. Shaded area $=$ nectary tissue. $d$, Proximal portion of the prolongation. Shaded area $=$ nectary tissue. Two stylar canals $(s c)$ are present on the adaxial side of nectary. $e$, Top of locules showing empty locules $(l o)$ and two stylar canals $(s c)$. Shaded area $=$ nectary tissue. $f$, Mid-locular region with two rows of ovules per locule $(l o)$.

The ovaries of the Costaceae investigated in this study vary in size (table 1). The distance from the attachment of the pedicel to the attachment of the perianth ranges from 8.9 to $21.3 \mathrm{~mm}$. Variations also occur in the length of locules, prolongation, and nectary (table l).

The ovary is either bilaterally symmetrical and bilocular (Monocostus uniflorus, Tapeinocheilas ananassae, Dimerocostus strobilaceus; figs. 3-5) or radially symmetrical and trilocular (Costus $d u$ bius; fig. 6). In the distal portion of the locular region of $T$. ananassae and $D$. strobilaceus there is an aerenchymatous region present abaxial to the central axis in the position where the third locule would appear (figs. 7, 8). The comparable region of aerenchyma in $M$. uniflorus is small and confluent with the circumlocular aerenchymatous region (fig. 9, ae). Ovules are borne on axile placentas with two (M. uniflorus, $T$. ananassae; fig. 9) or four (D. strobilaceus, C. dubius; fig. 10) rows of ovules per locule. Ovules occur below (M. uniflorus, T. ananassae, D. strobilaceus) or both above and below (C. dubius) the insertion of the stylar canals (figs. 3-6). Stylar canals rise from the locules just below and lateral to each locular apex (M. uniflorus, T. ananassae, C. dubius; figs. 3a, 4a, 6a) or at the apex of each locule (D. strobilaceus; fig. 5a). In the proximal portion of the prolongation, there are two or three stylar canals. When two are present they traverse the ovary on the adaxial side of the nectary ( $M$ uniflorus, T. ananassae, D. strobilaceus; figs. 3d, 4d, $5 \mathrm{~d})$. When three stylar canals are present they occur near the center of the central axis, between the lobes of nectary tissue (C. dubius; fig. 6d ). In the distal portion of the prolongation, there are one (M. uniflorus; fig. 3c), two (T. ananassae, fig. $4 c$; D. strobilaceus, fig. $5 c)$, or three (C. dubius; fig. 6c) stylar canals occurring near the center of the central axis. When multiple stylar canals are 


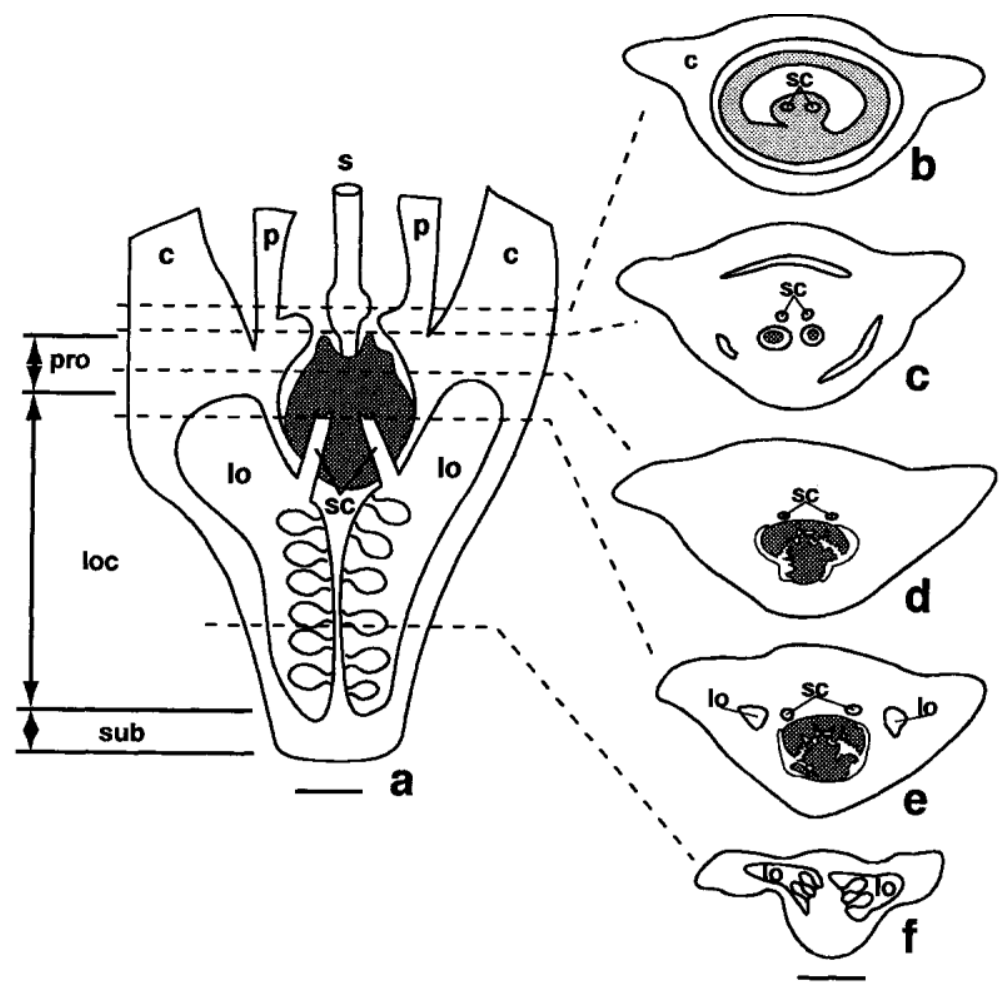

Fig. 4 Diagrams of mature ovary of Tapeinocheilas ananassae. a, Longitudinal diagram of the ovary. The three regions of the ovary are the sublocular $(s u b)$, locular $(l o c)$, and prolongation ( pro). The nectary (shaded) lies between the tops of the locules $(l o)$ and in the prolongation. $c=$ synsepalous calyx; $p=$ petals; $s=$ style (the insertion of the style is distorted to show the opening of the nectary ducts); $s c=$ stylar canals (truncated; see $b-e$ for their course); bar $=1.85 \mathrm{~mm} . b-f$, Cross sections of the ovary at the levels indicated in $a$. Bar $=2.5 \mathrm{~mm} . b$, Corolla attachment. $c=$ synsepalous calyx; lightly shaded area $=$ corolla and style; $s c=$ stylar canals. $c$, Calyx attachment. The tips of the nectary (shaded) are enclosed in the lumen of the nonsecretory nectary ducts. Two stylar canals $(s c)$ are present adaxial to the nectary ducts. $d$, Distal portion of the prolongation. Nectary tissue (shaded) partially surrounded by the nectary duct. Two stylar canals $(s c)$ present on the adaxial side of nectary. $e$, Top of locules showing empty locules $(l o)$ and two stylar canals $(s c)$. Shaded area $=$ nectary tissue. $f$, Mid-locular region with two rows of ovules per locule $(l o)$.

present, they join to form a single canal below the level of perianth attachment (M. uniflorus, $D$. strobilaceus, $C$. dubius) or just above the perianth attachment, in the style (T. ananassae). The stylar canal is bibbed (M. uniflorus, T. ananassae, D. strobilaceus) or trilobed (C. dubius) in the style, reflecting the number of locules in the ovary.

A nectary occurs between the tops of locules and extends distally into the prolongation $(M$. uniflorus, T. ananassae, C. dubius; figs. $3 \mathrm{a}, 4 \mathrm{a}$, $6 a)$ or occurs only in the prolongation $(D$. strobilaceus; fig. 5a). The nectary secretory tissue consists of highly convoluted, finger-like projections (T. ananassae, D. strobilaceus; figs. 11, 12) or is divided into a few smoothly rounded lobes (M. uniflorus, $C$. dubius; fig. 13). In $D$. strobilaceus a triradiate canal occupies the central axis in the proximal portion of the prolongation (fig. 21). Near the top of the nectary, tips of the secretory tissue lie in the lumen of the nectary duct(s) (figs. $3 c, 4 c, 5 c, 6 c, 23$ ). Above the nectary, the duct decreases in size and complexity until it ends in one or two pores (fig. 12). One duct and one pore (M. uniflorus, D. strobilaceus; figs. $3 a-c, 5 a-c$,
12 ) or two ducts and two pores (T. ananassae, $C$. dubius; figs. $4 \mathrm{a}, c ; 6 a, c)$ occur above the nectary. The nectary duct(s) of the bilocular species lie abaxially to the stylar canals in the central axis (M. uniflorus, T. ananassae, D. strobilaceus; figs. $3 c, 4 c, 5 c)$; in the trilocular ovary, the two ducts alternate with the stylar canals on the abaxial side of the ovary (C. dubius; fig. $6 c$ ). The pore(s) open at the top of the ovary near the base of the style, on the abaxial side of the style. The corolla tube functions as a nectar reservoir at the base of the perianth.

\section{HISTOLOGY OFTHE OVARY (FIGS. 14-26)}

The organography and histology of the individual species are presented in table 1 . The following is a composite description that includes all of the significant variations found among the species investigated in the study.

SUBLOCULAR REGION. Figure 14 shows a cross section through the sublocular region of an $M$. uniflorus ovary. Epidermis simple, of rectangular or cuboidal cells with prominent nuclei; with or 


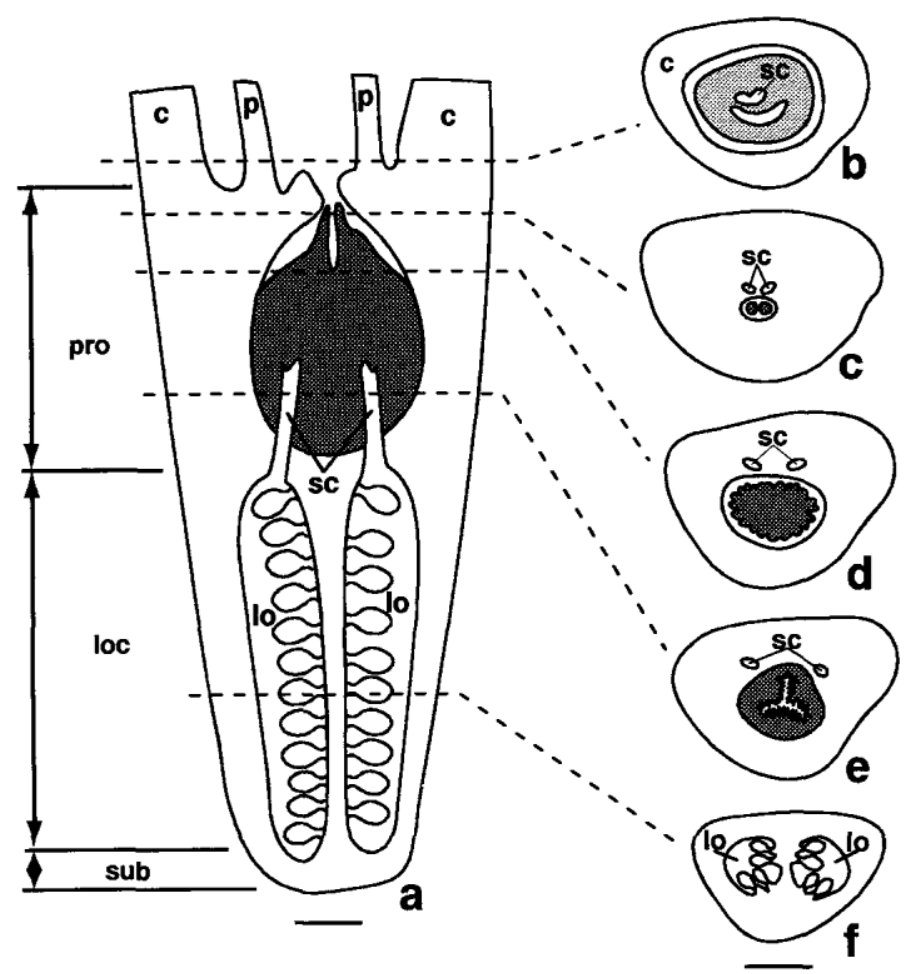

Fig. 5 Diagrams of mature ovary of Dimerocostus strobilaceus. a, Longitudinal diagram of ovary. The three regions of the ovary are the sublocular $(s u b)$, locular $(l o c)$, and prolongation ( pro). The nectary (shaded) lies in the prolongation. $c=$ synsepalous calyx; $p=$ petals; $s c=$ stylar canals (truncated; see $b-e$ for their course); $l o=$ locules; bar $=1.96 \mathrm{~mm}$. $b-f$, Cross sections of ovary at the levels indicated in $a$. Bar $=2.28 \mathrm{~mm} . b$, Perianth attachment. $c=$ synsepalous calyx; lightly shaded area $=$ corolla and style; $s c=$ stylar canal; curved slit $=$ nectary pore at top of ovary. $c$, Distal portion of the prolongation. The tips of the nectary are enclosed in the nonsecretory nectary duct. Two stylar canals $(s c)$ are present in the central axis. $d$, Mid-prolongation. Nectary tissue (shaded) surrounded by an enlarged, nonsecretory nectary duct. Two stylar canals (sc) present on the adaxial side of the nectary. $e$, Proximal portion of the prolongation. Two stylar canals $(s c)$ present on adaxial side of the nectary. Shaded area $=$ nectary tissue. $f$, Mid-locular region with four rows of ovules per locule $(l o)$.

without a thickened outer cell wall. Trichomes present or absent; when present, unicellular or multicellular. Hypodermis present or absent; when present, one to three layers of isodiametric or columnar cells with few to no intercellular spaces. Vascular zone with ground tissue of isodiametric parenchyma cells or aerenchyma. One outer ring of vascular bundles present with additional bundles scattered throughout the central axis, or vascular bundles irregularly arranged. In D. strobilaceus aerenchyma occupies the positions where locules will occur at a higher level. Tanniniferous idioblasts absent from epidermis, present elsewhere in ground tissue.

LOCULAR REGION. Figure 15 shows a cross section through the midlocular region of an $M$. uniflorus ovary. Epidermis as in sublocular region. Hypodermis one to 10 layers of columnar or isodiametric cells with few to no intercellular spaces. Monocostus uniflorus: proximally, hypodermal cells normally proportioned columnar cells (fig. 18); distally, hypodermal cells very thin and long (fig. 19), the hypodermal cells abaxial to the large vascular bundles slightly smaller (fig. 19, arrow). Tapeinocheilas ananassae: hypoder mis present only in the upper half of the region (fig. 20). Vascular zone interior to the hypodermis, with considerable diversity in composition among the species. Ground tissue of aerenchyma (fig. 24), or of isodiametric parenchyma cells with occasional intercellular spaces. In the latter case, a layer of aerenchyma surrounds the locules (fig. 15 , arrows). Vascular bundles in one ring with additional bundles irregularly arranged. One to three layers of isodiametric parenchyma cells always present directly adjacent to the locules. Locule epithelium simple, of rectangular or cuboidal cells with prominent nuclei. Stylar canals arising laterally or apically from the locules, lined with a densely cytoplasmic, cuboidal, or columnar epithelium. Nectary present or absent at this level with considerable variation in nectary structure among species. When present, surrounded by multiple layers of small, isodiametric parenchyma cells directly adjacent to the nectary. Nectary duct lined with epithelium of cuboidal or rectangular cells; cell walls facing lumen thickened or not thickened. Secretory tissue of isodiametric, densely cytoplasmic cells with few to no intercellular spaces; vascular bundles small and numerous, interspersed with secretory cells. Secre- 


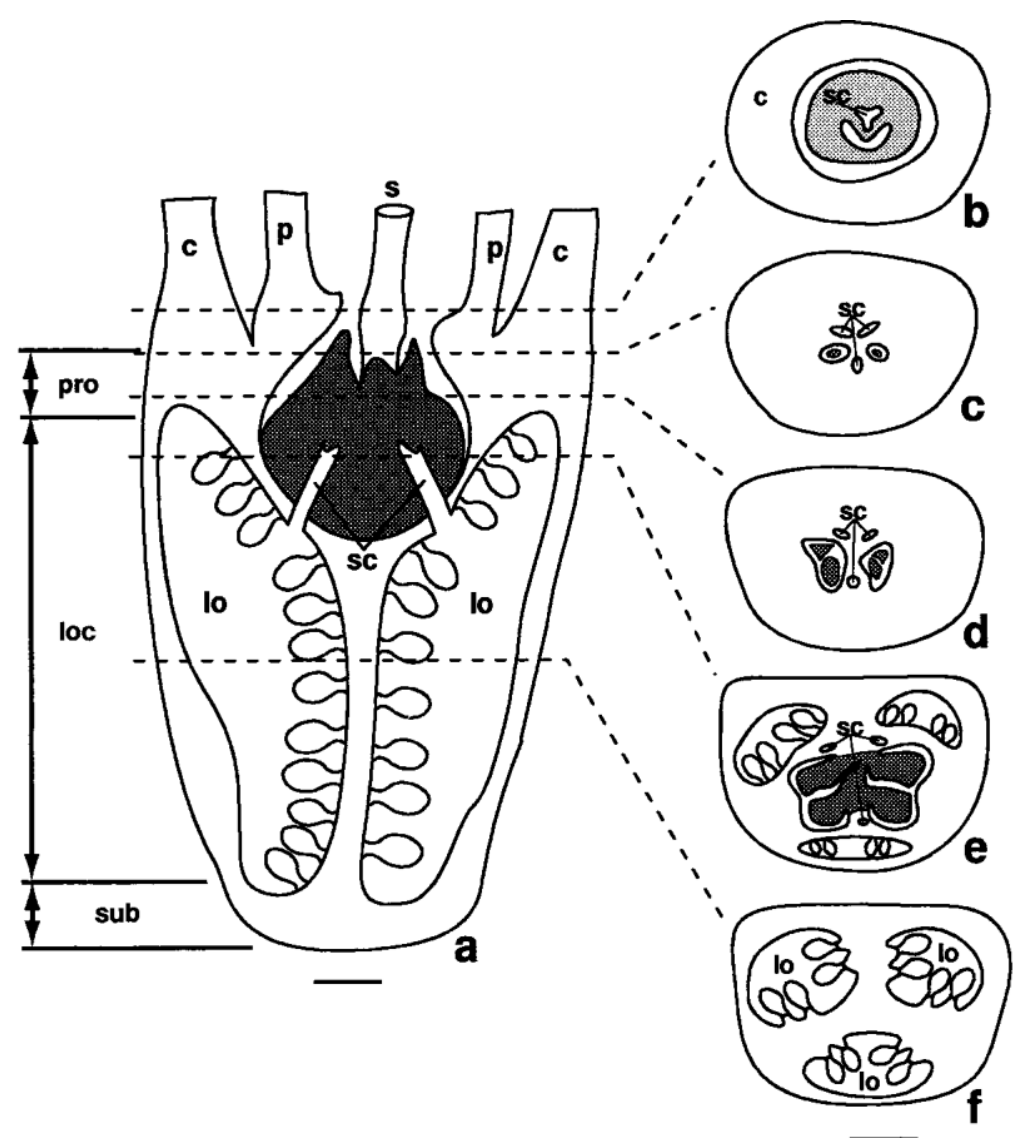

Fig. 6 Diagrams of mature ovary of Costus dubius. a, Longitudinal diagram of the ovary. The three regions of the ovary are the sublocular (sub), locular (loc), and prolongation (pro). The nectary (shaded) lies between the tops of the locules $(l o)$ and in the prolongation. $c=$ synsepalous calyx; $p=$ petals; $s=$ style (the insertion of the style is distorted to show the opening of the nectary ducts); $s c=$ stylar canals (truncated; see $b-e$ for their course); bar $=0.86 \mathrm{~mm} . b-f$, Cross sections of ovary at the levels indicated in $a$. Bar $=1.5 \mathrm{~mm}$. $b$, Perianth attachment. $c=$ synsepalous calyx; lightly shaded area $=$ corolla and style; curved slit $=$ nectary pores at top of ovary. $c$, Distal portion of the prolongation. The tips of the nectary (shaded) are enclosed in the lumen of the nonsecretory nectary ducts. Three stylar canals $(s c)$ present in the central axis. $d$, Proximal portion of the prolongation. Nectary tissue (shaded) surrounded by enlarged nectary ducts. Three stylar canals $(s c)$ present near the central axis. $e$, Top of locules with four ovules per locule and three stylar canals $(s c)$ present. Shaded area $=$ nectary tissue. $f$, Midlocular region with four rows of ovules per locule $(l o)$.

tory tissue with a simple epithelium of cuboidal or columnar cells with prominent nuclei, distinguishable from underlying cells by shape and very dark staining; outer walls of epithelium facing lumen not thickened. Central axis differs proximally and distally. Proximally, of isodiametric parenchyma interspersed with vasculature, or a mixture of isodiametric parenchyma and aerenchyma, and with vasculature in a dense band between the locules (fig. 22). Distally, nectary present or absent; when absent, vasculature arranged in center of the axis. Tanniniferous idioblasts absent from epidermis and epithelia; present throughout ground tissue of other regions. There is a concentration of tanniniferous idioblasts surrounding the locules in C. dubius.

PROLONGATION. Figure 16 shows a cross section through the prolongation of an $M$. uniflorus ovary. Epidermis simple, of rectangular or cu boidal cells with prominent nuclei; with or without a thickened outer cell wall. Trichomes present or absent; when present, unicellular or multicellular. Hypodermis one to 10 layers of columnar or isodiametric cells with few to no intercellular spaces. Vascular zone interior to the hypodermis with considerable diversity in composition among species. Ground tissue of isodiametric parenchyma cells with occasional intercellular spaces. Vascular bundles in one to three rings with additional bundles irregularly arranged; vascular plexus present in inner two-thirds of this zone. Dimerocostus strobilaceus: bundle sheaths present in the distal portion of the zone. Costus dubius: the vascular zone differs proximally and distally - proximally, the vascular zone consists of ca. 30 layers of isodiametric parenchyma cells (fig. 25, vz), vascular bundles arranged in three rings, one ring near the hypodermis and two in the middle of the zone; in the upper part of this region a vas- 


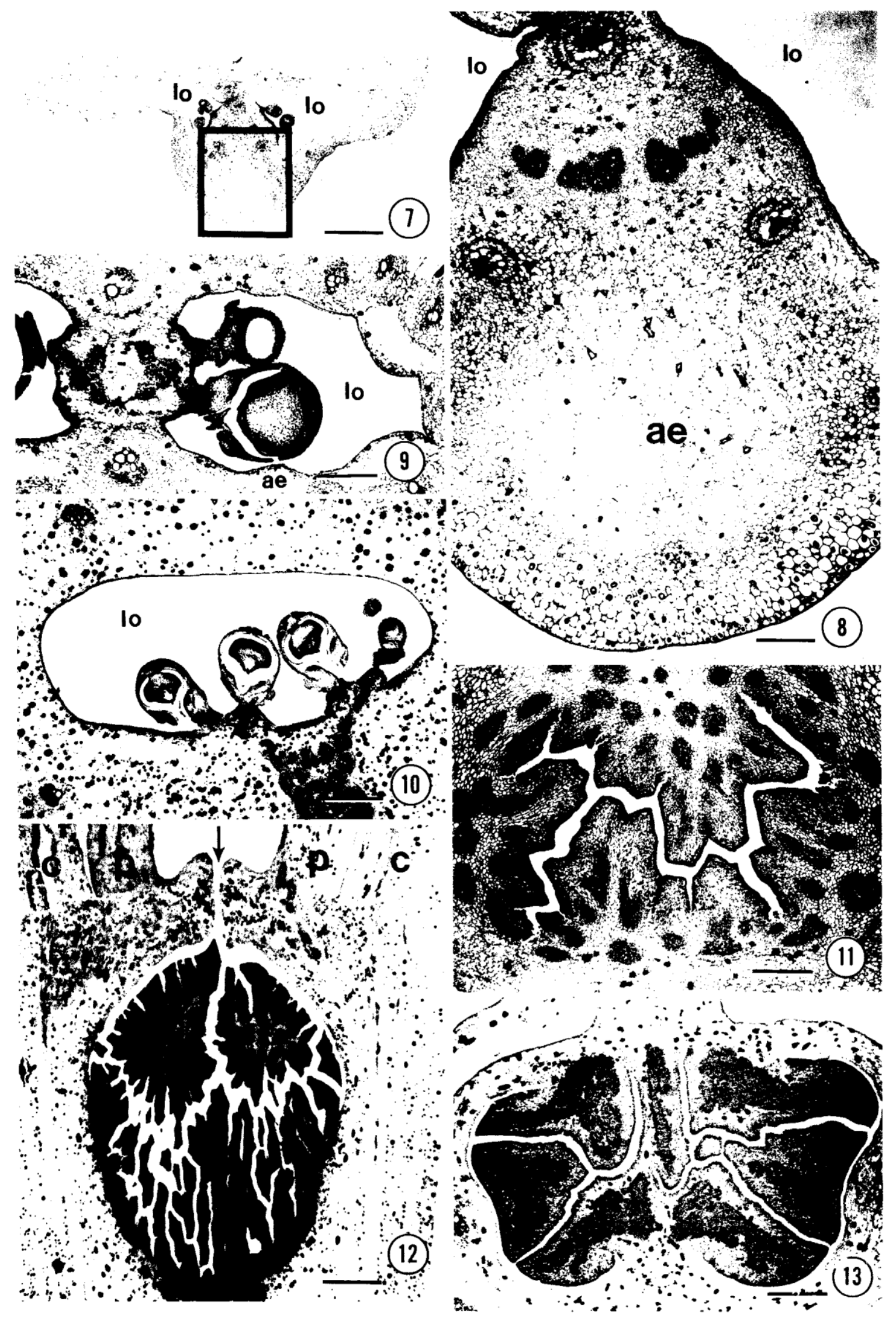


cular plexus present among the two inner rings of the zone (fig. 25); distally, ground tissue arranged in two irregular cylinders that can be distinguished by cell size (fig. 26, cl, c2), the outer cylinder $(c /)$ of six to 10 layers of large to medium-sized isodiametric parenchyma cells, large vascular bundles with bundle sheaths arranged in a single ring near the hypodermis; inner cylinder (c2) of ca. 20 layers of small isodiametric parenchyma cells, vascular bundles arranged in two rings with a vascular plexus present among the bundles of the rings. Stylar canals lined with densely cytoplasmic, cuboidal, or cuboidal to columnar, epithelium with prominent nuclei. $\mathrm{Nec}$ tary present, with considerable variation in nectary structure among species. Nectary duct lined with epithelium of cuboidal, columnar, or rectangular cells; cell walls facing lumen may or may not be thickened. Secretory tissue as in locular region. Secretory tissue epithelium of cuboidal or columnar cells; outer walls of epithelium facing lumen may or may not be thickened. Monocostus uniflorus, T. ananassae, D. strobilaceus: nectary surrounded by multiple layers of small, isodiametric parenchyma cells directly adjacent to the nectary. Central axis proximally containing nectary; distally, containing isodiametric parenchyma cells with a small zone of densely cytoplasmic, isodiametric cells surrounding the stylar canals. Dimerocostus strobilaceus, T. ananassae: stylar canals surrounded by sclerified cells in the distal portion of the central axis (fig. 17). Tanniniferous idioblasts absent from epidermis and epithelia; present throughout ground tissue of remaining regions. A concentration of tanniniferous idioblasts surrounds the stylar canals in all species.

\section{Discussion}

Similar patterns of ovary structure exist in the four genera of Costaceae examined in this study. The major portion of the ovary is the locular region, with a small sublocular region below, and a prolongation above the locules. A vascular plexus occurs just below the attachment of the perianth, and a floral nectary is present near the top of the ovary. The placentation is axile (Maas 1972, 1977; Dahlgren et al. 1985).

The number of fertile locules varies between two (Monocostus uniflorus, Tapeinocheilas an anassae, Dimerocostus strobilaceus) and three (Costus dubius) and agrees with previous reports (Maas 1972, 1977; Dahlgren et al. 1985). Although M. uniflorus, T. ananassae, and D. strobilaceus are bilocular, the plan of ovary construction is trilocular in these species, although less strongly so in $M$. uniflorus than in the other two species. Evidence for the trilocular plan of construction comes from the presence and distribution of aerenchyma, the position of the locules, the paths of the stylar canals, and a literature report of abnormal bilocular flowers in the Zingiberaceae (Rao 1963).

Aerenchymatous regions occur in D. strobilaceus and $T$. ananassae (figs. 7,8 ) on the abaxial side of the ovary, in a position corresponding to the third locule in C. dubius (fig. 6f ). In T. ananassae (fig. 4f) and D. strobilaceus (fig. 5f) the two existing locules are located on the adaxial side of the ovary, in positions comparable to the two adaxial locules in Costus. The comparable region of aerenchyma in $M$. uniflorus is small, occurs only in the distal portion of the ovary, and is confluent with the circumlocular aerenchymatous region.

The path of the stylar canals also supports a trilocular plan of construction. The path of the two stylar canals of all three bilocular species is on the adaxial side of the ovary (figs. 3-5), in a position similar to the two adaxial stylar canals of $C$. dubius (fig. 6). These observations indicate that the "missing" third locule of the bilocular species should be on the abaxial side of the ovary in a position corresponding to the third, abaxial locule of Costus.

Further evidence for this interpretation comes from abnormal flowers of Hedychium coronarium and Alpinia mutica (Zingiberaceae) (Rao 1963; A. mutica is cited as Catimbium muticum). The normal ovary of both of these species is trilocular. However, Rao (1963) observed abnormal flowers with bilocular ovaries. The loculi of these abnormal flowers are lateral in position with a median septum, as in M. uniflorus (fig. 3f ). This observation suggests a developmental mechanism for the production of bilocular ovaries. A normal trilocular ovary is formed from three conduplicate gynoecial primordia (Van Heel 1988): one anterior and two posterolateral. These pri-

Figs. 7-13 Sections of ovaries and nectaries. Tanniniferous idioblasts (black bodies) present throughout. Figs. 7, 8, Tapeinocheilas ananassae. Fig. 7, Cross section of the ovary at mid-locular region. lo = locules; bar $=1.55 \mathrm{~mm}$. Area in box enlarged in fig. 8. Fig. 8, Enlargement of box in fig. 7 showing aerenchyma (ae) abaxial to locules $(l o)$. Bar $=3.85$ mm. Figs. 9, 10, Cross sections through mid-locular regions of mature ovaries showing rows of ovules per locule. Fig. 9, Monocostus uniflorus with two rows of ovules per locule $(l o)$. Note the aerenchyma $(a e)$ surrounding the locules. Bar $=0.31 \mathrm{~mm}$. Fig. 10, Dimerocostus strobilaceus with four rows of ovules per locule $(l o)$. Bar $=0.43 \mathrm{~mm}$. Fig. 11, Tapeinocheilas ananassae. Cross section of lobes of secretory tissue with finger-like projections that interdigitate. Bar $=0.41 \mathrm{~mm}$. Fig. 12 , Dimerocostus strobilaceus. Longitudinal section through the nectary in the prolongation. The nectary duct (arrow), which opens at the top of the ovary, is enlarged to surround the distal portion of the nectary. $c=$ synsepalous calyx; $p=$ petals; bar $=1.2 \mathrm{~mm}$. Fig. 13, Costus dubius. Cross section of smooth-surfaced lobes of secretory tissue. Bar $=0.41 \mathrm{~mm}$. 

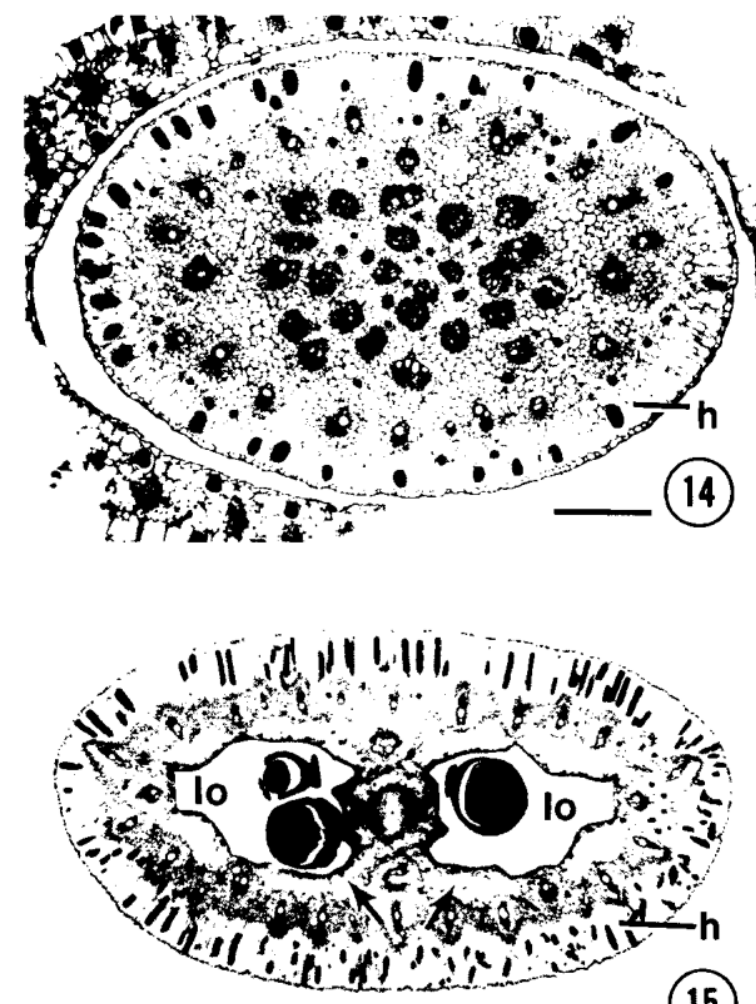

15

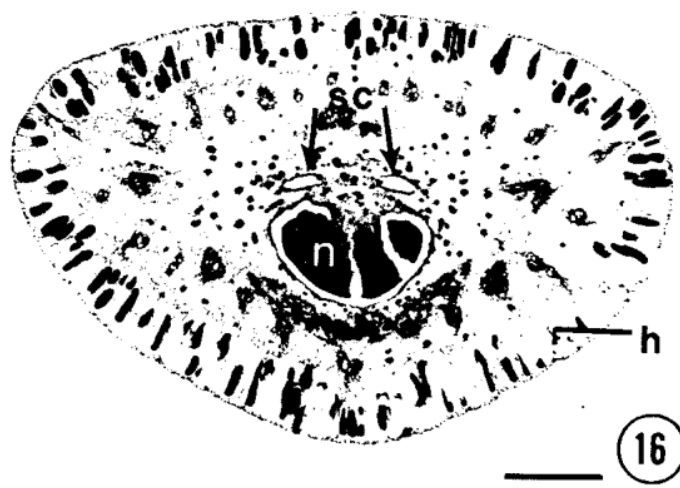

Figs. 14-16 Monocostus uniflorus. Cross sections of mature ovary. Tanniniferous idioblasts (black bodies) present throughout. Fig. 14, Cross section through the sublocular region. Remnants of the enclosing bract visible surrounding the ovary. $h=$ hypodermis; bar $=0.43 \mathrm{~mm}$. Fig. 15 , Cross section through mid-locular region. $h=$ hypodermis; $l o=$ locules; arrows $=$ aerenchyma; bar $=72 \mathrm{~mm}$. Fig. 16, Cross section through mid-prolongation. $h=$ hypodermis; $s c=$ stylar canals; $n=$ nectary; bar $=0.72 \mathrm{~mm}$.

mordia produce three septa: one posterior and two anterolateral (e.g., C. dubius; fig. $6 f$ ). If the development of the gynoecial primordium on the anterior side of the ovary were aborted, the anterolateral septa would form on the midline and fuse into a single septum with a median orientation (e.g., M. uniflorus; fig. 3f ).

The number of rows of ovules in each locule varies among the Costaceae. D. strobilaceus and $C$. dubius have four rows of ovules per locule. This report is in partial agreement with Banerji's (1940) report of two to four rows of ovules per locule in Costus speciosus. Monocostus uniflorus and $T$. ananassae have two rows of ovules per locule. Without additional research, it is not possible to determine whether two or four rows of ovules per locule is the primitive condition for the Costaceae.

The character "number of rows of ovules per locule" was used by Dahlgren and Rasmussen (1983) in their phylogenetic analysis of the Zingiberales. They report the states of this character as "one row per locule" versus "more than one row per locule." The families with "one row per locule" are listed as the Heliconiaceae and Marantaceae. However, these families have, at most, a single ovule (total) per locule (Marantaceae: Woodson and Schery 1945; Andersson 1981; and Kennedy et al. 1988; Heliconia: Kress 1984). A more adequate coding of this character should include character states for a single ovule, two and four rows of ovules per locule.

The extent of the locules that contain ovules varies among the genera of the Costaceae. In $M$. uniflorus, T. ananassae, and D. strobilaceus ovules occur only below insertion of the stylar canals. In $C$. dubius ovules occur both above and below insertion of these canals. Although it is difficult to account for this difference, the placement of the nectary between the tops of the locules might influence the lower placement of ovules in $T$. ananassae and M. uniflorus. However, in $C$. $d u$ bius the nectary occurs between the tops of the locules at the same level at which ovules are found. Perhaps factors affecting pollination could help explain the absence of ovules at the tops of the locules in some species.

The stylar canals arise from the locules in a lateral position in three species $(C$. dubius, $M$. uniflorus, $T$. ananassae), while in D. strobilaceus the canals arise from the apex of the locules. Since the origin of the stylar canals is presented here for the first time in the Zingiberales, it is not yet possible to evaluate the usefulness of this character for phylogenetic analysis.

The presence of an apical prolongation of the ovary is an unusual feature of the Costaceae. Unfortunately, the amount of tissue that occurs above the locules and closes an inferior ovary is not usually discussed in the literature. Inferior ovaries of some monocotyledons collected from the greenhouse of the University of North Carolina at Greensboro have only a small amount of tissue in the closure (ca. $1 \mathrm{~mm}$ or less). These were Taccaceae (Tacca sp.) and unidentified species of Bromeliaceae and Amaryllidaceae. If this length is representative of the common state of this character in monocotyledons, then the $2-3 \mathrm{~mm}$ found 

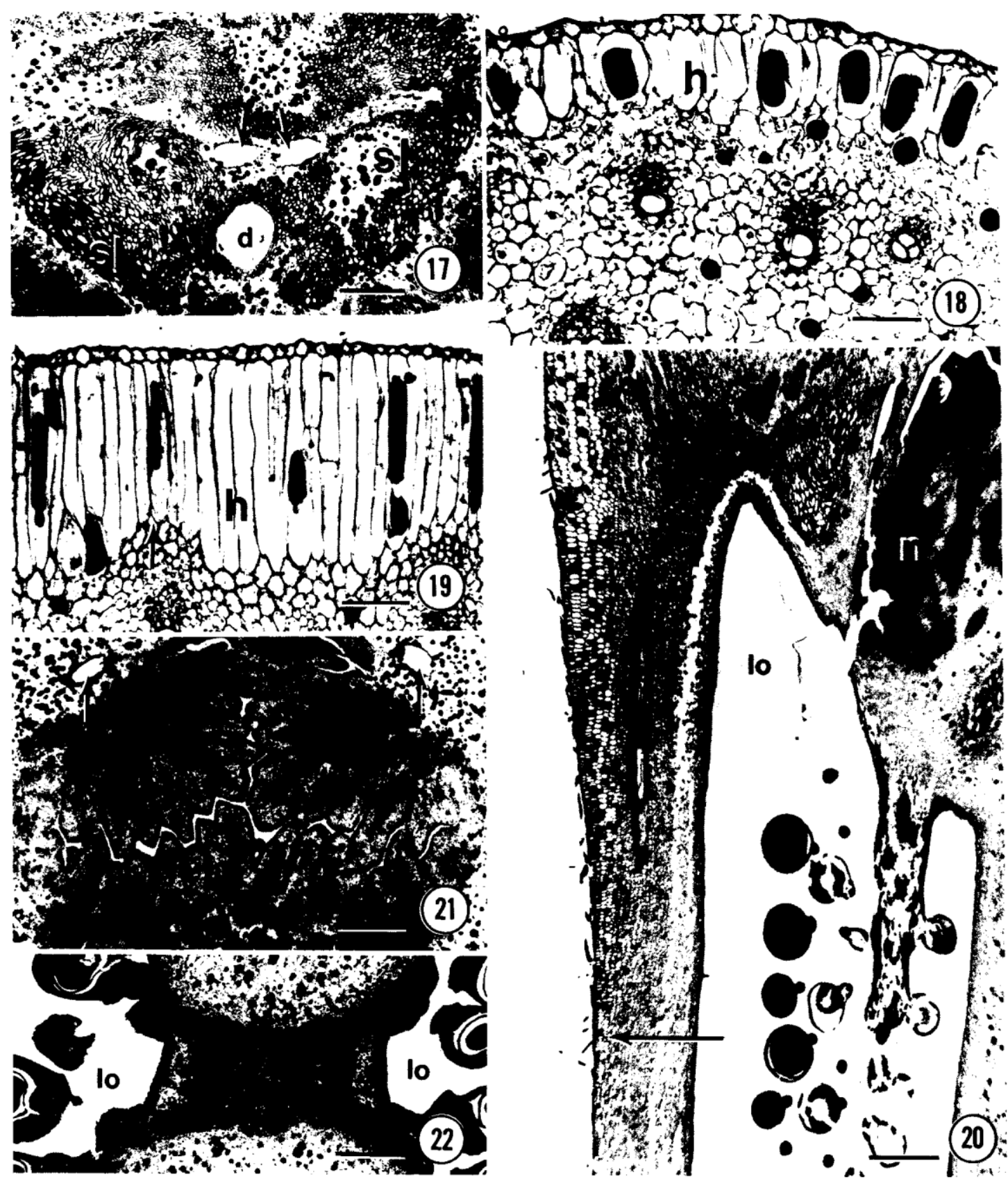

Figs. 17-22 Sections of ovaries and nectaries. Fig. 17, Dimerocostus strobilaceus. Cross section through the distal portion of the prolongation. Sclerified cells $(s l)$ surrounding the nectary duct $(d)$ and the two stylar canals (arrows). Bar $=0.57 \mathrm{~mm}$. Figs. 18,19, Monocostus uniflorus. Cross sections of hypodermis $(h)$ at different levels in the locular region. Fig. 18, Basal portion of the locular region. $h=$ hypodermis; bar $=0.04 \mathrm{~mm}$. Fig. 19, Mid-locular region. The hypodermis $(h)$ is of extremely long, columnar parenchyma. Where vascular bundles are very large, the hypodermal cells occurring abaxial to the bundles are slightly smaller (arrow). Bar $=0.13 \mathrm{~mm}$. Fig. 20, Tapeinocheilas ananassae. Longitudinal section of ovary showing the distal portion of the locular region. Arrow indicates the approximate level at which the hypodermis becomes distinct. $n=$ nectary; $l o=$ locules; bar $=0.5 \mathrm{~mm}$. Figs. 21, 22, Dimerocostus strobilaceus. Fig. 21, Cross section through the nectary at mid-prolongation. Note the three lobes of highly folded secretory tissue that abut to form a triradiate canal. arrows $=$ stylar canals; bar $=0.57$ $\mathrm{mm}$. Fig. 22, Cross section of central axis of ovary in the mid-locular region. The vascular bundles in the central axis are arranged in a band between the locules $(l o)$. Bar $=0.57 \mathrm{~mm}$.

in T. ananassae, C. dubius, and M. uniflorus is a considerable deviation from the norm, and the 8 $\mathrm{mm}$ prolongation of $D$. strobilaceus is exceptional.

In Dahlgren and Rasmussen's (1983) character set for phylogenetic analysis of the Zingiberales, they referred to a character termed "hypanthiumlike neck" of the ovary (p. 352). Only the Lowiaceae are listed as possessing this character. Although the prolongation in the Costaceae is much 


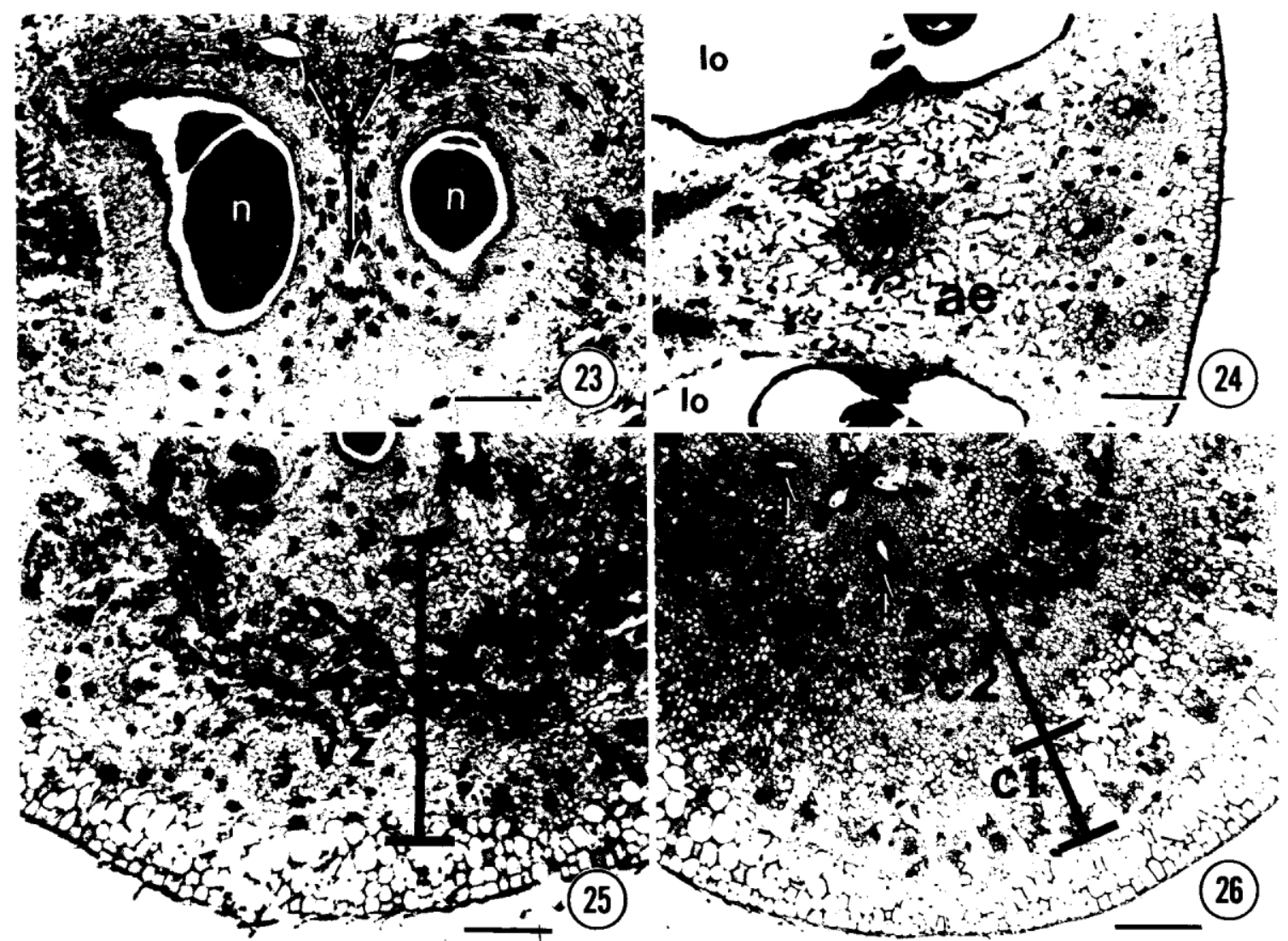

Figs. 23-26 Costus dubius. Cross sections of ovary at different levels. Fig. 23, Mid-prolongation. Nectary tissue $(n)$ present in the lumen of the nonsecretory nectary ducts. Three separate stylar canals $(s c)$ occur near the nectary ducts. Bar $=0.4 \mathrm{~mm}$. Fig. 24, Mid-ovary. Septa between two locules $(l o)$ showing the aerenchymatous $(a e)$ ground tissue. Bar $=0.36 \mathrm{~mm}$. Fig. 25 , Proximal portion of the prolongation. $v z=$ vascular zone including the vascular plexus. The three rings of vascular tissue are not visible in this photograph. Bar $=0.42 \mathrm{~mm}$. Fig. 26, Distal portion of the prolongation. $c 1=$ outer vascular cylinder; $c 2=$ inner vascular cylinder with vascular plexus. The stylar canals ( $s c$ ) and nectary ducts (arrows) occur in the central axis. Bar $=$ $0.46 \mathrm{~mm}$.

shorter than that found in the Lowiaceae (Holtturn 1970; Larsen 1983), its presence is significant. Like the Lowiaceae, the Strelitziaceae possess extreme extensions of the ovary in all three genera (Strelitzia: Kronestedt and Walles 1986; Phenakospermum, Ravenala: Kirchoff and Newman, unpublished). Further investigations of the size of the closure of inferior ovaries may result in this feature becoming a valuable character for phylogenetic analysis of the Zingiberales.

Floral nectaries are a prominent feature of the ovaries of the Costaceae. The nectary of Costus speciosus has been described as septal by Brown (1938) and Van Heel (1988). However, the unusual structure of these nectaries causes a number of problems with this interpretation. In normal septal nectaries the nectary ducts are lined with a secretory epithelium and lie in the same radius as the septa, alternating with the locules (Schmid 1985). In the case in which the nectary ducts are combined, a triradiate duct is formed in the central axis of the ovary. The arms of this duct lie in the septal planes. The nectaries of the Costa ceae differ from these normal septal nectaries in at least three respects: their position is at least partially above the locules; the number of nectary ducts, or arms of the duct, does not correspond to the number of septa; the nectary ducts are lined, at least in part, by a nonsecretory epithelium. We deal with each of these differences and their relation to the interpretation of the nectaries in turn.

The sole fact that the nectaries occur above the locules presents no problem to their interpretation as septal, or septal derived, nectaries. Schmid (1985) and Van Heel (1988) point out that septal nectaries frequently do not lie directly in the septa but are often found on the same radius. In Hemerocallis flava L. (Van Heel 1988) and Heliconia spp. (Kirchoff, unpublished) the septal nectaries lie primarily below the locules. Thus, the position of the nectaries in the Costaceae above the locules should not preclude them from being considered septal.

Smets and Cresens (1988) suggest the term "gynopleural nectaries" to replace septal nectar- 
ies, at least in part as a response to observations like those cited above. They point out that the literal sense of the term "septal" does not cover those cases in which the nectary originates on the same radius as the septa, but not in the septa. Neither does it cover the unusual placement of the nectaries in the Costaceae. We will use the term gynopleural nectary for the remainder of this article unless we are citing a study in which the author refers to "septal nectaries."

We consider the fact that the number of nectary ducts does not correspond to the number of septa a potentially serious problem with the interpretation of the nectaries of the Costaceae as gynopleural. To see this problem clearly, consider the situation in D. strobilaceus (fig. 5e, $f$ ) and $C$. dubius (fig. 6e, f). Dimerocostus strobilaceus has two locules, but a short distance above the locules the nectary duct possesses three arms that lie in what would be the septa of a trilocular ovary. Costus dubius has three locules, but the nectary can, at best, only be interpreted as composed of two (fused) lobes. These lobes lie in the two anterolateral septa. The posterior septum does not possess a nectary duct.

Van Heel's (1988) study of the development of gynoecia with septal nectaries suggests a resolution of these problems. He found that septal nectaries only form when the margins of the carpels arise free from each other. His photographs of $C$. speciosus demonstrate that this occurs only in the anterolateral positions, not the posterior. The margins of the carpels in the latter region arise "fused" to each other. Thus, the lack of the appropriate developmental conditions prohibits the formation of a nectary duct in this region. Kirchoff (1988a) described a similar developmental pattern in the ovary of Costus scaber Ruiz and Pavon. Thus, in $C$. dubius the lack of a nectary duct in the posterior position may be correlated with the "congenital fusion" of the carpel margins that produce this region of the ovary. A similar explanation could explain the structure of the nectary in $T$. ananassae in which the main nectary ducts lie in anterolateral positions (fig. $4 \mathrm{~d}$, e).

We can also speculate on the origin of the nectary ducts in D. strobilaceus based on Van Heel's (1988) observations, but in this case the explanation is not so facile. In this case, we must postulate a change in the pattern of carpel development to accommodate our observations. While we are uncomfortable suggesting an explanation without hard evidence to support it, we do so here in the hope that this hypothesis will stimulate further research on gynoecial development in the Costaceae. It may be that the margins of the posterior carpels remain free during ovary development in D. strobilaceus. This would permit the formation of nectary ducts in all three septa, as is found in this species (fig. 5e). However, this explanation does not account for the enclosure of a solid mass of secretory tissue in the nectary duct at higher levels in the prolongation (fig. 5d).

The structure of the nectary in M. uniflorus is much more difficult to explain. Here only the portion of the nectary duct that lies in the median plane can be interpreted as occurring in a septum (fig. $3 d, e$ ). This observation, and the fact that there is little evidence for the existence of a third locule in M. uniflorus (see above), suggests that the anterior carpel is reduced or lost. That is, it is never initiated or forms only a small portion of the ovary. In either case, the developmental change would produce a septum in the median plane of the ovary. The "fusion" of the carpel margins in the posterior region (Kirchoff 1988a; Van Heel 1988) might explain the placement of the nectary slightly on the abaxial side of the ovary (figs. 3e, 16).

The existence of a nonsecretory epithelium in parts of the nectary duct is the third difference we noted between the nectaries of the Costaceae and more common gynopleural nectaries. In the above discussion, we ignored these nonsecretory regions, concentrating instead on the regions with a secretory lining. The structure of the secretory regions of the nectary duct corresponds closely to the structure of the epithelia of other gynopleural nectaries in the Zingiberales (Musaceae: Fahn et al. 1961; Strelitziaceae: Kronestedt and Walles 1986; Heliconiaceae: Kirchoff, unpublished; Cannaceae: Pai 1965; Maas and Maas 1988; Marantaceae: Rao 1975). The placement of the nonsecretory ducts in the locular region does not correspond to the septa in any of the species studied here. The existence and placement of the nonsecretory ducts causes us to suggest that they originate from some secondary process, not primarily connected with the production of gynopleural nectaries.

Despite the problems mentioned above, we think that the nectaries of the Costaceae are gynopleural or at least are derived from gynopleural nectaries. Support for their origin from more typical gynopleural nectaries comes from the work of Kulkarni and Pai (1982), who described the nectary in Puya spathacea Mez. (Bromeliaceae). This nectary shows similarities to those of the Costaceae, in which portions of the secretory tissue are enclosed in nonsecretory ducts. These authors suggest that the nectary condition in $P$. spathacea may be considered a transitional "type" between normal septal nectaries and the unusual nectary of Costaceae.

An important aspect of the floral nectaries of the Costaceae is their relationship to the epigynous glands of Zingiberaceae, the sister group of the Costaceae (Dahlgren and Rasmussen 1983; 
Kress 1990). Brown (1938) was the first to suggest a relationship between the nectaries of Costus and those of the Zingiberaceae. This idea was picked up by Rendle (1956) and Cronquist (1968), who state that the epigynous glands of the Zingiberaceae are derived from septal nectaries. Rao (1963) also supports this conclusion based on his studies of floral structure of the Zingiberaceae and of $C$. speciosus (Rao et al. 1954; Rao and Pai 1959, 1960; Rao and Gupte 1961). In C. speciosus the nectary ducts do not lie in the septa but opposite the locules. Rao (1963) suggests that the two anterolateral secretory regions (note: Rao is referring to regions of nectary tissue, not nectary ducts) in C. speciosus represent the ancestral condition for the epigynous glands of the Zingiberaceae. The epigynous glands of the Zingiberaceae occur on vertical lines corresponding to these two anterolateral regions. However, since the positions of the nectary ducts do not correspond to the septa, the nectaries of $C$. speciosus could not have originated from normal gynopleural nectaries. Thus, the derivation of the nectaries of the Zingiberaceae, and of $C$. speciosus, remains unclear. However, we agree that the origins of these nectaries must be sought in the gynopleural nectaries of the rest of the Zingiberales. The exact mechanism of their origin is all that is lacking.

Floral nectary types in the Zingiberales include gynopleural nectaries (Strelitziaceae, Heliconiaceae, Cannaceae, and Marantaceae), the modified gynopleural nectaries of the Musaceae (Fahn et al. 1961) and Costaceae, and the epigynous glands of the Zingiberaceae. The Lowiaceae lack floral nectaries (Kirchoff 1988b).

In his analysis of the phylogeny of the Zingi- variable character that he omitted from his analysis. We hope this article has contributed to the better understanding of the structure of the nectaries in this order and that it will soon be possible to include floral nectary characters for use in a phylogenetic analysis of the order.

This investigation of ovary structure in the Costaceae supports the close relationship among the four genera of the family. The structure and position of the nectary is undoubtedly an autapomorphy of the family. Other characteristics that may be autapomorphies are the presence of a well-differentiated hypodermis and the possession of a nonsecretory lining in portions of the nectary duct. However, the states of these characters must be investigated in the other families of the Zingiberales before a definite conclusion can be reached.

\section{Acknowledgments}

This article based on a thesis by S. W. H. Newman submitted to the faculty of the Graduate School at the University of North Carolina at Greensboro (UNCG) in partial fulfillment of the requirements for the degree Master of Arts. We thank the personnel of Lyon and Waimea Arboreta and Bishop Museum, all on Oahu, Hawaii, for making their facilities available to us during this study. This article is based on work supported by grants from Ciba-Geigy, Sigma $\mathrm{Xi}$, and the UNCG Graduate Student Council to S. W. H. Newman, and a Summer Excellence Foundation Grant from UNCG and grant BSR-880178 from the National Science Foundation to B. K. $V$ :.mon ff

\section{Literature cited}

Andersson, L. 1981. The neotropical genera of Marantaceae: circumscription and relationships. Nord. J. Bot. 1:218-245.

Banerji, I. 1940. A contribution to the life-history of Costus speciosus Smith. J. Indian Bot. Soc. 19:181-196.

Berlyn, G. P., and J. P. Miksche. 1976. Botanical microtechnique and cytochemistry. Iowa State University Press, Ames.

Bissing, D. R. 1974. Haupt's gelatin adhesive mixed with formalin for affixing paraffin sections to slides. Stain Technol. 49:116-117.

Brown, W. H. 1938. The bearing of nectaries on the phylogeny of flowering plants. Proc. Am. Philos. Soc. 79:549595.

Cronquist, A. 1968. The evolution and classification of flowering plants. Thomas Nelson, London.

Dahlgren, R. M. T., H. T. Clifford, and P. F. Yeo. 1985. The families of the Monocotyledons. Springer-Verlag, Berlin.

Dahlgren, R. M. T., and F. N. Rasmussen. 1983. Monocotyledon evolution: characters and phylogenetic estimation. Evol. Biol. 16:255-395.

Fahn, A., N. Klarman-Kislev, and D. Ziv. 1961. The abnormal flower and fruit of May-flowering Dwarf Cavendish bananas. Bot. Gaz. 123:116-125.
Holttum, R. E. 1970. The genus Orchidantha (Lowiaceae). Gard. Bull. (Singapore) 25:239-247.

Johansen, D. A. 1940. Plant microtechnique. McGraw-Hill, New York.

Kennedy, H., L. Andersson, and M. Hagberg. 1988. Marantaceae. Pages 11-192 in G. Harling and L. Andersson, eds. Flora of Ecuador. No. 32. Department of Systematic Botany, University of Goteborg, Stockholm.

Kirchoff, B. K. 1988a. Inflorescence and flower development in Costus scaber (Costaceae). Can. J. Bot. 66:339345 .

. 1988 b. The structure of the ovary in the Strelitziaceae and Lowiaceae, support for the close relationship of these families. Am. J. Bot. 75(6, pt. 2):185-186.

Kress, W. J. 1984. Systematics of Central American Heliconia (Heliconiaceae) with pendent inflorescences. J. Arnold Arbor. Harv. Univ. 65:429-532.

. 1990. The phylogeny and classification of the Zingiberales. Ann. Mo. Bot. Gard. 77:698-721.

Kronestedt, E., and B. Walles. 1986. Anatomy of the Strelitzia reginae flower (Strelitziaceae). Nord. J. Bot. 6:307320 .

Kulkarni, R. A., and R. M. Pai. 1982. The floral anatomy of Puya spathacea Mez. (Bromeliaceae) with special ref- 
erence to nectaries. Proc. Indian Acad. Sci. Sect. B 91:473478.

Larsen, K. 1983. Lowiaceae. Pages 147-150 in J.-F. Leroy, ed. Flore du Cambodge du Laos et du Viet-Nam. Museum National D'Histoire Naturelle, Paris.

Maas, P. J. M. 1972. Costoideae (Zingiberaceae). Pages 1125 in C. T. Rogerson, ed. Flora Neotropica. New York Botanical Garden, Monograph 8. Hafner, N.Y. 1976. Zingiberaceae. Pages 1-47 in G. Harling and B. Sparre, eds. Flora of Ecuador. No. 6. Department of Systematic Botany, University of Goteborg, Stockholm. . 1977. Renealmia (Zingiberaceae - Zingiberoideae) Costoideae (additions) (Zingiberaceae). Pages 160-209 in

C. T. Rogerson ed. Flora Neotropica. New York Botanical Garden, Monograph 18. Hafner, New York. 1979. Zingiberaceae. Pages 416-441 in A. L. Stoffers and J. C. Lindeman, eds. Flora of Suriname. Vol. 5. Pt. 1. E. J. Brill, Leiden. 1985. Zingiberaceae. Pages 29-67 in A. R. A. GortsVan-Rijn ed. Flora of the Guianas. Koeltz Scientific Books, Königstein, Germany.

Maas, P. J. M., and H. Maas. 1988. Cannaceae. Pages 1-9 in G. Harling and L. Andersson, eds. Flora of Ecuador. No. 32. Department of Systematic Botany, University of Goteborg, Stockholm.

Nakai, T. 1941. Notulae ad Plantas Asiae Orientalis (XVI). J. Jpn. Bot. 17:189-210.

Pai, R. M. 1965. Morphology of the flower in the Cannaceae. J. Biol. Sci. 8:4-8.

1966. The floral anatomy of Kaempferia rosea

Schweinf. ex Benth. with special reference to the glands in Zingiberaceae. Proc. Indian Acad. Sci. Sect. B 64:83-90. Panchaksharappa, M. G. 1962. Taxonomic evaluation of Zingiberaceae. Bull. Bot. Surv. India 4:129-135.

Postek, M. T., and S. C. Tucker. 1976. A new short chemical dehydration method for light microscopy preparations of plant material. Can. J. Bot. 54:872-875.

Rao, V. S. 1963. The epigynous glands of Zingiberaceae. New Phytol. 62:342-349.
1975. Septal glands: their form, structure and function. Pages 375-378 in H. Y. M. Ram, T. T. Shah, and C. K. Shah, eds. Form, structure and function in plants. Sarita Prakasham, India.

Rao, V. S., and K. Gupte. 1961. The floral anatomy of some Scitamineae. IV. J. Univ. Bombay 29:134-150.

Rao, V. S., H. Karnik, and K. Gupte. 1954. The floral anatomy of some Scitamineae. I. J. Indian Bot. Soc. 33:118 147.

Rao, V. S., and R. M. Pai. 1959. The floral anatomy of some Scitamineae. II. J. Univ. Bombay 28:82-114.

1960. The floral anatomy of some Scitamineae. III.

J. Univ. Bombay 28:1-19.

Rendle, A. B. 1956. The classification of flowering plants. Vol. 1. Gymnosperms and monocotyledons. Cambridge University Press, London.

Schmid, R. 1985. Functional interpretations of the morphology and anatomy of septal nectaries. Acta Bot. Neerl. 34:125-128.

Schumann, K. 1904. Zingiberaceae. Pages 1-458 in H. G. A. Engler, ed. Das Pflanzenreich IV. Vol. 46. Engelmann, Leipzig.

Smets, E. F., and E. M. Cresens. 1988. Types of floral nectaries and the concepts "character" and "character-state" a reconsideration. Acta Bot. Neerl. 37:121-128.

Takhtajan, A. 1969. Flowering plants: origin and dispersal. Smithsonian Institution Press, Washington, D.C. . 1980. Outline of the classification of flowering plants (Magnoliophyta). Bot. Rev. 46:225-359.

Tomlinson, P. B. 1956. Studies in the systematic anatomy of the Zingiberaceae. Bot. J. Linn. Soc. 55:547-592.

1962. Phylogeny of the Scitamineae-morphological and anatomical considerations. Evolution 16:192-213.

Van Heel, W. A. 1988. On the development of some gynoecia with septal nectaries. Blumea 33:477-504.

Woodson, R. E., Jr., and R. W. Schery. 1945. Flora of Panama. Pt. 3. Fascicle I. (Juncaceae-Marantaceae). Ann. Mo. Bot. Gard. 32:1-105. 